\title{
Can physicians regulate themselves?
}

[E]very doctor will allow a colleague to decimate a whole countryside sooner than violate the bond of professional etiquet [sic] by giving him away. — Bernard Shaw, Preface on Doctors, The Doctor's Dilemma, 1911

$\mathrm{P}$ atients want and need to have confidence in their physicians. Yet confidence in physicians is waning. In part this reflects the more generalized public distrust of experts and authority figures that has become characteristic of our age. But the public is increasingly aware that the quality and oversight of medical care are uneven. They are aware of an unexpectedly high frequency of adverse events, ${ }^{1}$ of reports of hospital and professional mismanagment, such as the pediatric cardiac surgery deaths in Winnipeg, ${ }^{2}$ and of professional malfeasance, whose most spectacular modern example is the murder of 250 patients over a 27-year period by Dr. Howard Shipman, a British family physician.

In Canada, responsibility for assuring the public that their physicians are competent lies with provincial licensing bodies. In the UK, that responsibility rests with the General Medical Council (GMC). The latter, following the outing of Dr. Shipman by the police (not the GMC), has come under intense scrutiny. It has been found not only wanting, but so mired in incompetence and professional self-interest that its continuing existence is in question.

Dame Janet Smith, in her fifth report on the Shipman Inquiry to the UK Secretary of State for Health ${ }^{3}$ is convinced that, had the GMC done its job properly, Shipman's serial murders would have been discovered and stopped decades earlier. The GMC, she wrote, despite the motto "Protecting Patients - Guiding Doctors" emblazoned on its letterhead, focused "too much on the interests of the doctors and not sufficiently on the protection of patients." She makes 109 recommendations, most of which are applicable to other countries, Canada included.

Dame Janet urges the broad adoption by all health care organizations from hospitals to solo practices of a management framework that focuses on continuous quality improvement, the safeguarding of high standards and the creation of an environment in which excellence can flourish.

o Such a clinical governance structure entails, among other things, continuing education, good management systems (for detecting errors), clinical audits, risk management and "an ethos of openness and accountability."

But the main focus of the report is the ongoing evaluation of physicians. Dame Janet faults the GMC for not providing adequate assessments of physician "fitness to prac- tise" and for its utter failure to establish an "ethos of openness and accountability" among physicians and health care establishments.

As is the case with provincial bodies in Canada, the GMC has recognized only recently that ongoing evaluations of physicians' fitness to practise are necessary: a single entry exam and a few letters of reference are not enough. Yet Dame Janet found that the GMC's recently implemented (and partly voluntary) evaluations were inadequate, especially in their almost exclusive focus on knowledge: "If appraisal is to be used to any extent as a summative tool [not just a formative one] it must be capable of detecting that small group of doctors who have something to hide." Dame Janet also calls for the monitoring of physician prescription profiles and for similar monitoring of referrals, patient complaints and physician-specific mortality data, to name but a few items.

Few physicians have not experienced what Shaw satirically described and Dame Janet grimly documented: questionable practice by colleagues that is witnessed but not reported. Of the many Shipman deaths reviewed by Dame Janet, that of Mrs. Renate Overton, a 46-year-old patient with asthma, became emblematic of the failure of physicians to identify colleagues who were unfit to practise. At a home visit for an acute asthma attack, Shipman gave Mrs. Overton $20 \mathrm{mg}$ of morphine either IV or IM in a single injection. The resulting cardiopulmonary arrest from which she was resuscitated and admitted to ICU left her in an irreversible coma; she died a year later. That Shipman had administered a contraindicated drug in a lethal dose was known by the senior physicians in charge of the ICU; it was never reported, nor was Shipman questioned.

Confidence in physicians is at the core of what we do. We need strong licensing and regulatory bodies, and we need to step up implementation of clinical governance structures whose mandate includes fostering a climate of openness and accountability. Otherwise someone will do it for us. - CMAf

\section{References}

1. Baker GR, Norton PG, Flintoft V, Blais R, Brown A, Cox J, et al. The Canadian Adverse Events Study: the incidence of adverse events among hospital patients in Canada. CMA7 2004;170(11):1678-86.

2. Davies JM. Painful inquiries: lessons from Winnipeg. CMA7 2001; 165(11):1503-4.

3. Smith J. Safeguarding patients: lessons from the past - proposals for the future. Command Paper Cm 6394. London (UK): The Shipman Inquiry; 2004 Dec 9. Available: www.the-shipman-inquiry.org.uk/reports.asp (accessed 2005 Feb 21). 